\title{
Resistance screening of lentil cultivars against the root-knot nematode Meloidogyne incognita
}

\author{
T. Ansari, M. Asif* and M.A. Siddiqui
}

Summary The root-knot nematode Meloidogyne incognita is a major soil parasite of lentil crops. Increasing restrictions of chemical nematicides have triggered a growing attention and interest in alternate root-knot nematode management. The present study was conducted to examine the level of resistance and/or susceptibility of five lentil cultivars (PL-456, KLS-218, Desi, DPL-62, Malika), grown in pots, against the root-knot nematode $M$. incognita. Root-knot nematode reproduction and host damage were assessed by recording the nematode infestation levels and reduction percentage of plant growth parameters. Nematode response and plant growth differentiated amongst the lentil cultivars. None of the cultivars was found immune or highly resistant. The cultivar Malika was found moderately resistant as it showed the lowest number of galls and egg masses/root as well as the lowest reduction of plant fresh weight (10.4\%) and dry weight (6.9\%). On the other hand, the cultivar Desi manifested the highest susceptibility exhibiting the highest number of galls and egg masses. There was a significantly negative correlation between the number of galls and plant growth parameters (plant fresh and dry weight and plant height).

Additional keywords: cultivars, lentil, Meloidogyne incognita, resistance, root-knot nematode

\section{Introduction}

Lentil (Lens culinaris Medik.) is one of the most important pulse crops and a major source of protein ( $30 \%$ weight, second protein content legume after soybeans) for the predominant vegetarian population of India. India ranks second (after Canada) in lentil production, with lentil cultivation occupying an area of 1,800,000 hectares and annual production reaching 1,100,000 metric tonnes of grain. The average yield is $6000 \mathrm{~kg} / \mathrm{ha}$ (FAO, 2014). Lentils are an important source for the Indian household income.

Meloidogyne spp. cause yield losses in pulses, which are estimated annually up to 20-35\% (Gaur et al., 2001). In India, the average loss caused by root-knot nematodes on pulses may be $14.6 \%$, and could go as high as $50-80 \%$ in some crops (Bhatti, 1992).

Root-knot nematodes are difficult to

Section of Plant Pathology and Nematology, Department of Botany, Aligarh Muslim University, Aligarh, India.

* Corresponding author: asifgc2616@gmail.com control because of their short life cycle, high population densities and reproductive potential (Sikora and Fernandez, 2005). The immense loss caused by root knot nematodes can be minimized by using various strategies such as soil treatment with chemicals, biocontrol agents (Vagelas and Gowen, 2012), cultural practices such as crop rotation, antagonistic plants (Hussain et al., 2011), resistant cultivars (Tariq et al., 2016) and soil amendments (Asif et al., 2017a, b; Ansari et al., 2016), which are common methods of nematode control.

Synthetic nematicides can rapidly reduce nematode population. However, their indiscriminate and consistent use can be toxic to beneficial soil flora and fauna, and may induce emergence of resistant plant parasitic nematodes (Akhtar, 1991). Nevertheless, nematode infestation levels in soil could be reduced by using resistant cultivars with crop rotation strategy of nonhosts. According to Oostenbrink (1966), the cultivation of a resistant cultivar may suppress the nematode population by $10-50 \%$ of its harmful density. Susceptibility of different pulse crops has been reported by sev- 
eral researchers such as Pandey et al. (2016) and Montasser et al. (2017). Sasser (1954) found that the roots of resistant plants were not invaded as rapidly as susceptible ones. Such variability in tolerance might be related to their genetic makeup, coding for a resistance mechanism possessed by the particular cultivar (Anwar and McKenry, 2007). All cultivars referred as resistant to root-knot nematodes have comparatively better crop yield as compared to susceptible cultivars (Mukhtar et al., 2014).

The present investigation was carried out as a resistance screening of five of the most commonly grown cultivars of lentil in India against Meloidogyne incognita (Kofoid and White) Chitwood under greenhouse conditions with a view to better exploit the use of most resistant cultivars for the suppression of root-knot nematodes in integrated management programmes.

\section{Materials and Methods}

Meloidogyne incognita was collected from naturally infested eggplant (Solanum melongena L.) fields near Punjipur village, Aligarh (U.P). Meloidogyne incognita was mass cultured from a single egg mass on a susceptible variety of tomato, S-22, in a greenhouse of the Section of Plant Pathology and Plant Nematology, Department of Botany, A.M.U., Aligarh. Second-stage juveniles (J2) were obtained from hatched eggs by incubating handpicked egg masses in sterile distilled water at $28 \pm 1^{\circ} \mathrm{C}$.

Seeds of five lentil cultivars namely, PL456, KLS-218, Desi, DPL-62 and Malika were obtained from the Indian Institute of Pulses Research, Kanpur, India as these are most commonly grown and chief cultivars concerning with the productivity of lentil in India. Lentil seeds of all five cultivars were surface sterilized with $0.1 \%$ mercuric chloride and sown in clay pots of $15 \mathrm{~cm}$ diameter containing $1 \mathrm{~kg}$ sterilized sandy loam soil. Four lentil seeds of each cultivar were sown per pot, which was considered one replication. The pots were placed in a greenhouse at a completely randomized design (CRD). The experiment had four replications per cultivar and it was repeated twice in time. Three weeks after seed germination, thinning was performed, leaving one plant per pot. Two days after thinning, approximately $1500 \mathrm{sec}-$ ond stage juveniles of $M$. incognita were pipetted around each plant by making holes in soil. A total of eight plants (four inoculated and four uninoculated) of each cultivar were used for this experiment. The uninoculated plants served as controls. Ninety days after inoculation, the plants were uprooted gently from the pots and different plant growth parameters were noted.

Varietal response against $M$. incognita infestation of different crops is accessed on the basis of growth parameters and nematode reproduction parameters (Hayat, 2011). Hence, in the present study data were recorded for plant growth viz., shoot height and root length, dry and fresh shoot and root weight, number of pods, number of nodules per root system, weight of 100 seeds and nematode reproduction parameters like number of egg masses, number of eggs/root system, root-knot index and final nematode population. Physiological parameters like chlorophyll content (MacKinney, 1941) and carotenoid content were also estimated. The percent increase and reduction in the growth parameters over the control were calculated by using the formula

$$
\begin{gathered}
\% \text { reduction or increase }= \\
\left(\frac{\text { Uninoculated }- \text { Inoculated }}{\text { Uninoculated }}\right) \times 100
\end{gathered}
$$

(Irshad et al., 2012; Mukhtar et al., 2014).

Analysis of Variance was conducted and the Duncan's Multiple Range Test was employed for the comparison of means between the cultivars according to Critical Difference (C.D.) at $P=0.05$ level. To detect relation between the parameters, Pearson correlation and multiple linear regression was performed. The data were analysed using SPSS 12.00 software (SPSS Inc., Chicago, IL, USA). 


\section{Results}

None of the cultivars was found immune according to the rating scale of Table 1 based on number of galls on the root system (Table 2). The resistance rating of the cultivars was: Malika (moderately resistant), KLS-218 (moderately susceptible), PL-456 (moderately susceptible), DPL-62 (susceptible), Desi (susceptible). The same trend was observed for the egg masses and the nematode population per root system (Table 2).

The cultivars Malika, KLS-218, PL-456 had a comparable shoot height before infestation by $M$. incognita, which was significantly higher than the one of the DPL-62 and Desi. After infestation by the nematode, Malika continued to have significantly high- er shoot compared to the other cultivars. These heights differentiated in the following descending order: KLS-218, PL-456, DPL62 and Desi (Table 3).

Prior to the infestation by the nematode, the root length of the cultivars Malika, KLS218, PL-456 was significantly higher than the one of the cultivars DPL-62 and Desi. After infestation, Malika had the least reduction in root length as compared to the other cultivars (Table 3).

The cultivar Malika had significantly heavier shoot fresh and dry weight than the other cultivars both before and after nematode infestation. The cultivars had the following decreasing order in shoot fresh and dry weights: KLS-218, PL-456, DPL-62 and Desi. A similar trend was also observed in

Table 1: Rating scale for the assessment of level of resistance of plant cultivars against rootknot nematodes, based on number of galls (Sasser and Taylor, 1978).

\begin{tabular}{c|c|c}
\hline Root knot Index & No. of galls/root system & Resistance rating \\
\hline 0 & 0 & Immune \\
1 & $1-2$ & Highly Resistant \\
2 & $3-10$ & Moderately Resistant \\
3 & $11-30$ & Moderately Susceptible \\
4 & $31-100$ & Susceptible \\
5 & $>100$ & Highly Susceptible \\
\hline
\end{tabular}

Table 2. Reproduction of the root-knot nematode Meloidogyne incognita on five lentil cultivars and resistance rating of the nematode.

\begin{tabular}{|c|c|c|c|c|c|c|}
\hline \multicolumn{2}{|c|}{ Cultivars } & $\begin{array}{c}\text { No. of } \\
\text { egg masses/ }\end{array}$ & No. of eggs/ & Nematode & Number of & Reaction \\
\hline Desi & $\begin{array}{c}\text { Control } \\
\text { Inoculated }\end{array}$ & $\begin{array}{c}- \\
112 \pm 0.43^{\mathrm{a}}\end{array}$ & $\begin{array}{c}- \\
196 \pm 0.40^{\mathrm{a}}\end{array}$ & $\begin{array}{c}- \\
2000 \pm 0.42^{\mathrm{a}}\end{array}$ & $\begin{array}{c}- \\
43 \pm 0.84^{a}\end{array}$ & Susceptible \\
\hline DPL-62 & $\begin{array}{c}\text { Control } \\
\text { Inoculated }\end{array}$ & $\begin{array}{c}- \\
89 \pm 0.48^{b}\end{array}$ & $\begin{array}{c}- \\
154 \pm 0.45^{b}\end{array}$ & $\begin{array}{c}- \\
1692 \pm 0.32^{\mathrm{b}}\end{array}$ & $\begin{array}{c}- \\
35 \pm 0.76^{b}\end{array}$ & Susceptible \\
\hline PL- 456 & $\begin{array}{c}\text { Control } \\
\text { Inoculated }\end{array}$ & $\begin{array}{c}- \\
58 \pm 0.72^{c}\end{array}$ & $\begin{array}{c}- \\
97 \pm 0.46^{c}\end{array}$ & $\begin{array}{c}- \\
1590 \pm 0.21 b^{c}\end{array}$ & $\begin{array}{c}- \\
24 \pm 0.72^{c}\end{array}$ & $\begin{array}{l}\text { Moderately } \\
\text { Susceptible }\end{array}$ \\
\hline KLS- 218 & $\begin{array}{c}\text { Control } \\
\text { Inoculated }\end{array}$ & $\begin{array}{c}- \\
26 \pm 0.88^{d}\end{array}$ & $\begin{array}{c}- \\
69 \pm 0.68^{d}\end{array}$ & $\begin{array}{c}- \\
1440 \pm 0.25 \mathrm{c}^{\mathrm{d}}\end{array}$ & $\begin{array}{c}- \\
16 \pm 0.88^{d}\end{array}$ & $\begin{array}{l}\text { Moderately } \\
\text { Susceptible }\end{array}$ \\
\hline Malika & $\begin{array}{c}\text { Control } \\
\text { Inoculated }\end{array}$ & $\begin{array}{c}- \\
8 \pm 1.20^{\mathrm{e}}\end{array}$ & $\begin{array}{c}- \\
25 \pm 1.15^{\mathrm{e}}\end{array}$ & $\begin{array}{c}- \\
1161 \pm 0.19^{\mathrm{e}}\end{array}$ & $\begin{array}{c}- \\
6 \pm 1.00^{\mathrm{e}}\end{array}$ & $\begin{array}{c}\text { Moderately } \\
\text { Resistant }\end{array}$ \\
\hline
\end{tabular}

Values are mean of eight replicates.

Values in each column followed by the same letters are not significantly different according to Duncan's Multiple Range Test $(P \leq 0.05)$. 


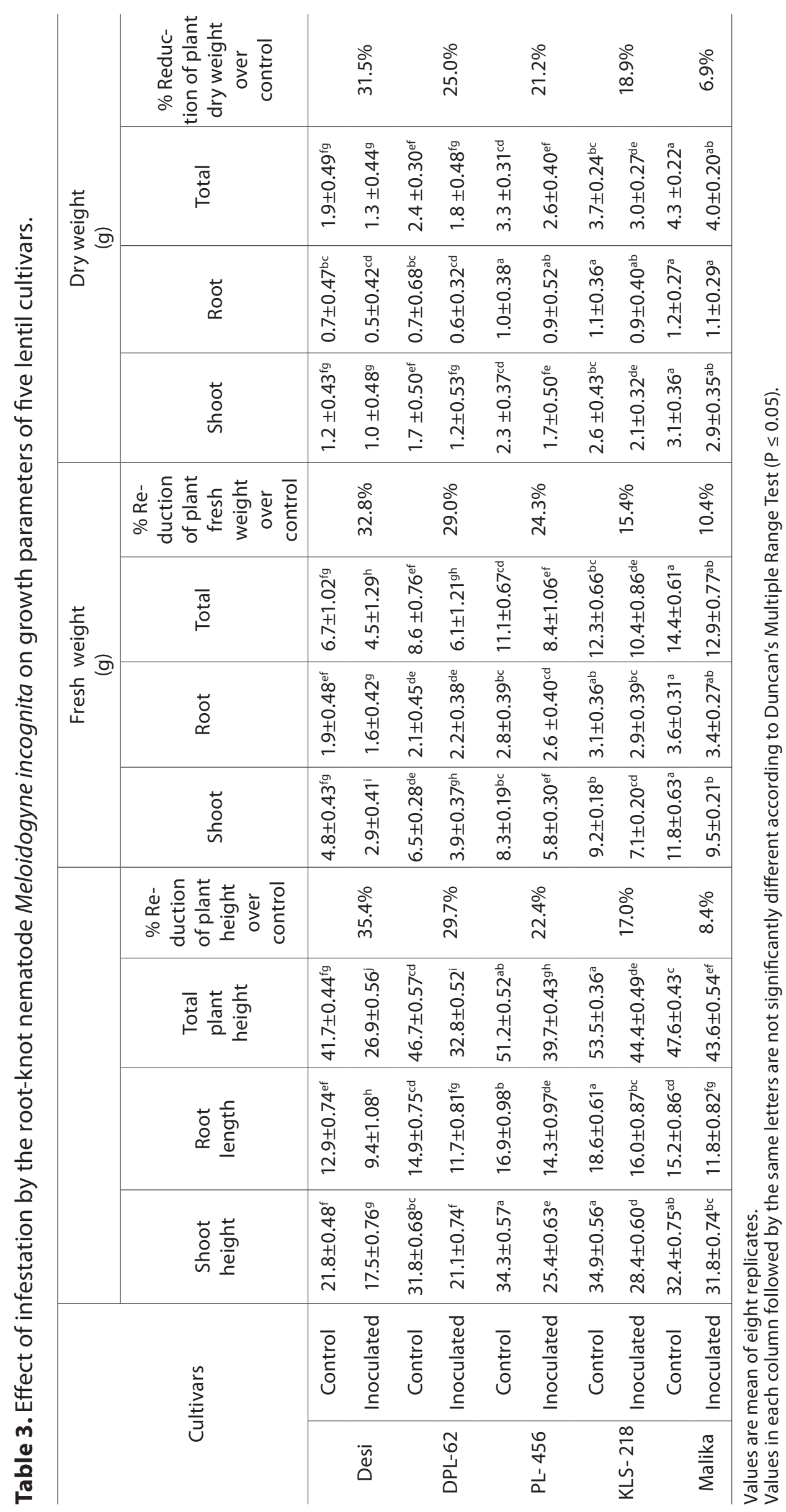


the root fresh and dry weight (Table 3).

When the higher number of nodules/ root system was compared between cultivars, Malika had significantly higher number of nodules/root system. Inoculation of $M$. incognita caused reduction in nodulation in all lentil cultivars. Malika continued to have significantly the highest number of nodules after nematode inoculation while Desi had the least number of nodules compared to the other cultivars (Table 4).

Yield parameters in terms of number of pods/plant and weight of seeds showed significant reductions after inoculation with nematodes in all lentil cultivars when compared to their respective controls. Among all cultivars, Malika had significantly more pods/plant and higher weight of seeds followed by KLS-218, PL-456, DPL-62 and Desi (Table 4).

Before infestation by $M$. incognita the cultivars Malika and KLS-218 had comparable chlorophyll and carotenoid content, which was significantly higher than PL-456, DPL-62 and Desi. Chlorophyll and carotenoid content of leaves was significantly reduced by nematode infestation in all lentil cultivars (Table 4).

Regression analysis showed a significant positive relation between the number of galls and reduction in plant fresh weight $\left(\mathrm{R}^{2}=0.974\right)$ (Fig. 1a), plant dry weight $\left(\mathrm{R}^{2}=0.930\right)$ (Fig. 1b), plant height $\left(R^{2}=0.997\right)$ (Fig. 1c), number of pods/plant $\left(R^{2}=0.988\right)$ (Fig. 1d), number of nodules/root system $\left(R^{2}=0.918\right)$ (Fig. 1e).

Pearson correlation coefficients $(r)$ indicate a significantly negative relation between nematode infestation parameters and all the plant growth parameters (Table 5): Total plant length $(r=-0.948, P=0.05)$, Total plant fresh weight $(r=-0.999, P=0.01)$, Total plant dry weight $(r=-0.995, P=0.01)$, No. of pods ( $r=-0.961, P=0.01)$, No. of nodules/ root system $(r=-0.974, P=0.01)$, Chlorophyll content $(r=-0.964, P=0.01)$, Carotenoid content $(r=-0.895, P=0.05)$. Correlation between weight of seeds and nematode infestation in terms of eggs, eggs/egg masses, nematode population and galls had a negative relation, but not significant.

\section{Discussion}

M. incognita failed to reproduce and multiply on the cultivar Malika and exhibited the lowest reduction in growth, responding as moderately resistant against $M$. incognita infestation. The cultivar Desi was the most susceptible to the root-knot nematodes. The cultivars KLS-218 and PL-456 showed a moderately susceptible response in terms of reproduction and an intermediate reduction in growth parameters, which was less severe than that observed for the susceptible cultivar. The cultivars PL-456 and DPL-62 were found moderately susceptible and susceptible, respectively, but showed less severe damage by the nematode as compared to the most susceptible cultivar.

Most of the plant growth characters of the lentil cultivars were significantly negative correlated with the number of galls of M. incognita. Moreover it can be suggested that eggs, eggs/egg masses and nematode population also had a direct effect on the reduction of plant growth. Meloidogyne spp. induces galling in the roots and giant cells formation in the stellar region, which destroys the xylem tissues and ultimately reduces the absorption and movement of water and nutrients (Abad et al., 2003). This limitation of nutrient elements in the plant is probably the first effect that the nematode infestation has on the physiology and metabolism of its host (Lu et al., 2014). These effects increase with the duration of infestation (Melakeberhan et al., 1987).

A reduction in total chlorophyll, as in the case of our experiment, has also been reported in French bean and rice infested by M. javanica (Melakeberhan et al., 1986; Swain and Prasad, 1988). Reduction in chlorophyll content has also been reported to lead to the disturbance of nodule function (Chahal et al., 1983).

In conclusion, the current study demonstrated that five of the most broadly cultivated lentil cultivars in India are susceptible to moderately susceptible to $M$. incognita with the exception of the cultivar Malika, which was found moderately resistant. The culti- 


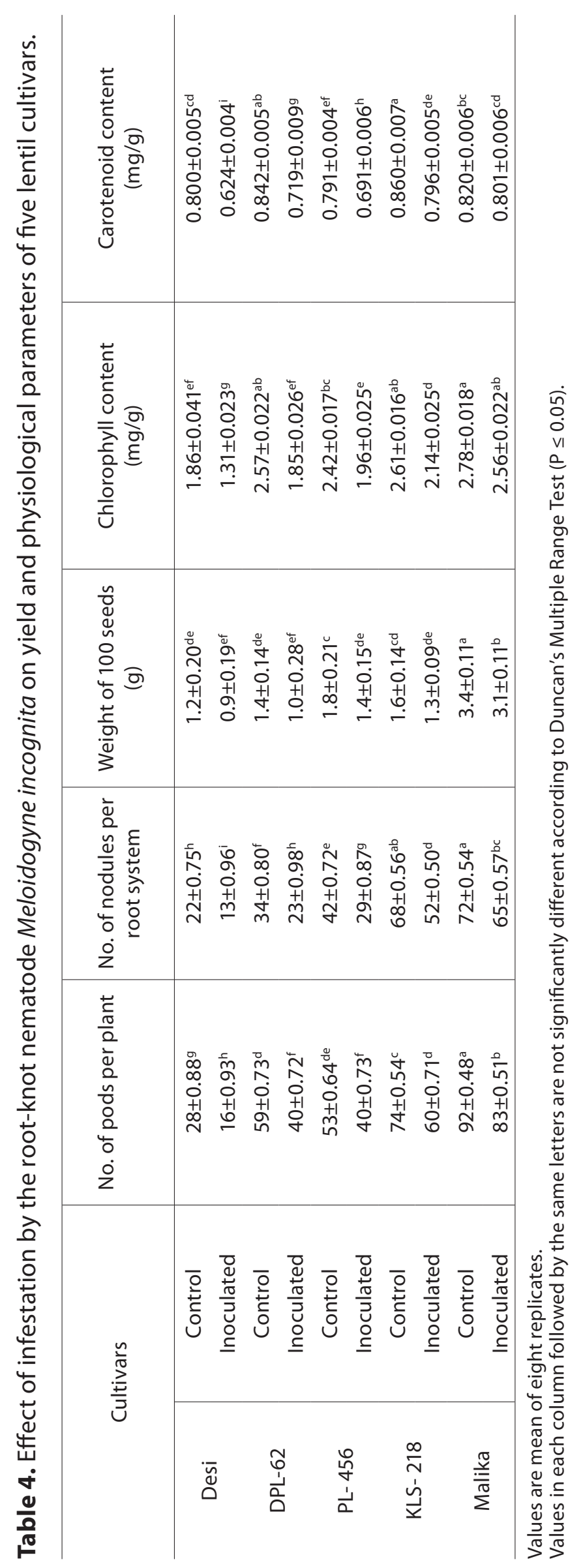



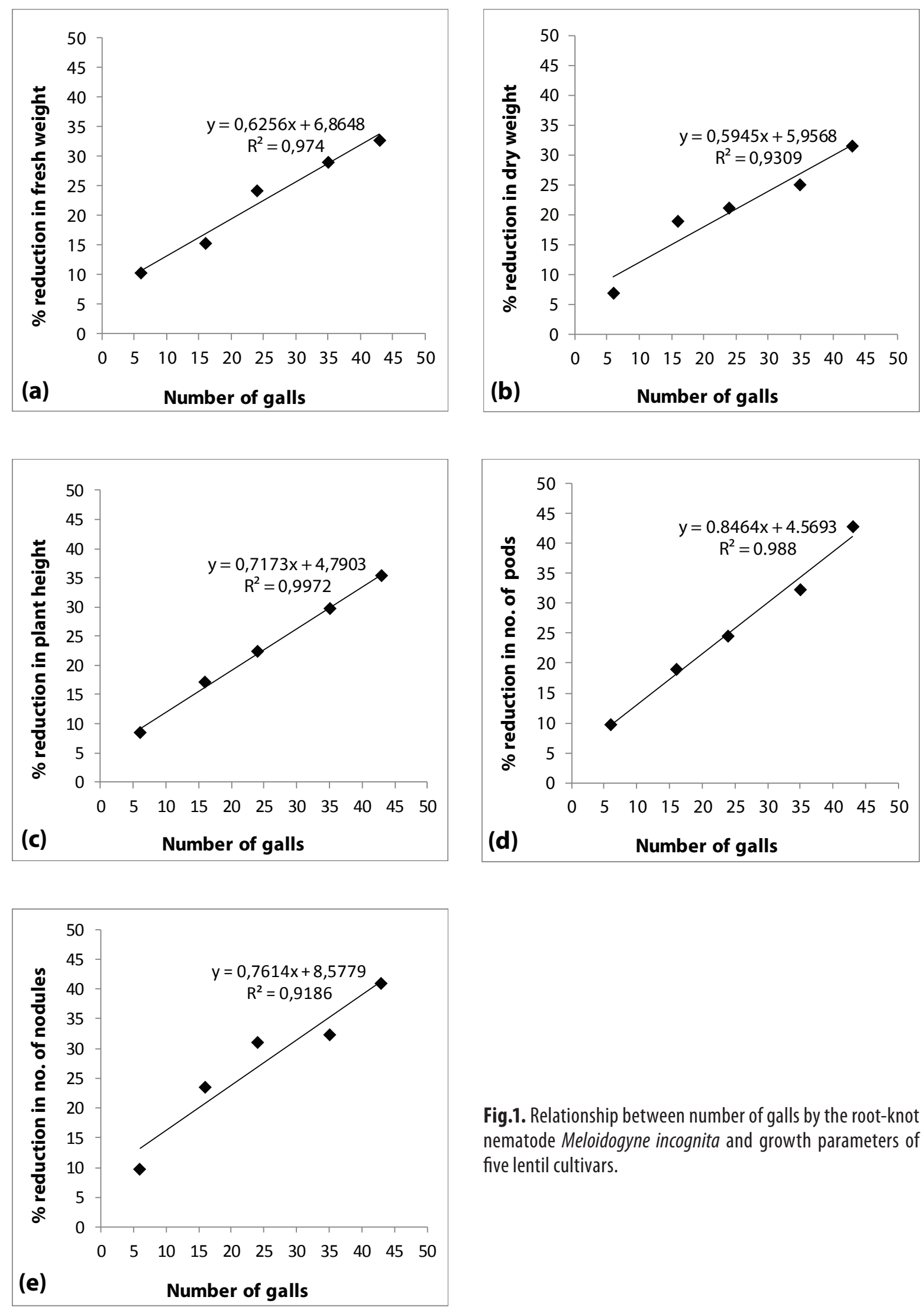

Fig.1. Relationship between number of galls by the root-knot nematode Meloidogyne incognita and growth parameters of five lentil cultivars. 


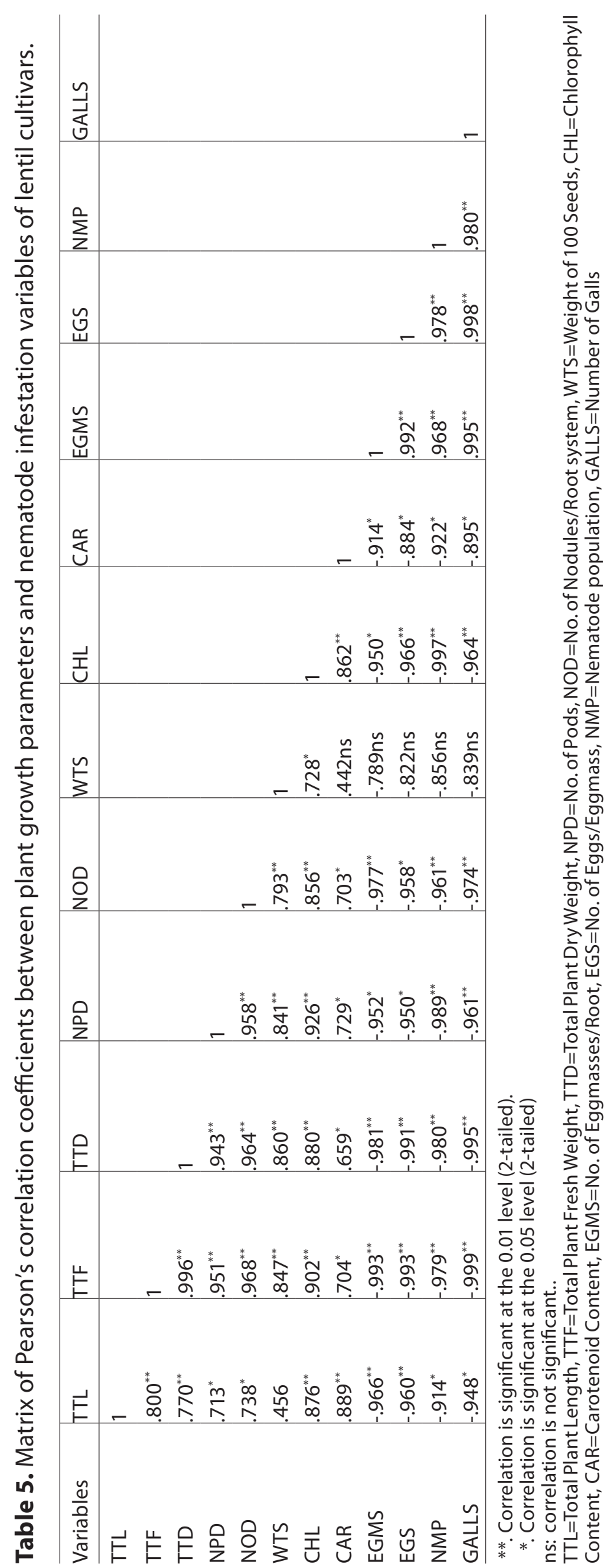


vars KLS-218 and PL-456 were moderately susceptible whereas DPL-62 and Desi were susceptible. There was an intense reduction of the plant growth parameters in susceptible cultivars as compared to less susceptible ones. Growing of the moderately resistant cultivar Malika in severely infested fields with $M$. incognita may assist to minimize root-knot nematode multiplication. Further studies are necessary in search of possibly higher resistance levels to root-knot nematodes in other commercially available lentil cultivars and the development of resistant cultivars.

The authors are grateful for financial support from the University Grant Commission, New Delhi (UGC-Non NET) and the chairman, Department of Botany for providing necessary assistance.

\section{Literature Cited}

Abad, P., Favery, B., Rosso, M. and Castagnone-Sereno, P. 2003. Root-knot nematode parasitism and host response: molecular basis of a sophisticated interaction. olecular Plant Pathology, 4: 217-224.

Akhtar, M. 1991. Studies on the management of plant parasitic nematodes with organic soil amendments. Ph.D. Thesis. Aligarh Muslim University, Aligarh, India, p. 195.

Ansari, T., Asif, M. and Siddiqui, M.A. 2016. Potential of botanicals for root knot management on tomato. Lambert academic Publishing. ISBN: 9783659910920.

Anwar, S.A. and McKenry, M.V. 2007. Variability in reproduction of four populations of Meloidogyne incognita on six cultivars of cotton. Journal of Nematology, 39(2): 105-110.

Asif, M., Khan, A., Tariq, M. and Siddiqui, M.A. 2017 a. Sustainable management of root knot nematode Meloidogyne incognita through organic amendment on Solanum lycopersicum L. Asian Journal of Biology, 1(1): 1-8.

Asif, M., Ahmad, F., Tariq, M., Khan, A., Ansari, T., Khan, F. and Siddiqui, M.A. 2017b. Potential of chitosan alone and in combination with agricultural wastes against the root knot nematode, Meloidogyne incognita infesting eggplant. Journal of Plant Protection Research, 57(3): 288-295.

Bhatti, D.S. 1992. In: Nematode pests of crops (Eds. D.S. Bhatti and R.K. Walia), CBS Publisher and
Distributors, Delhi, p. 344-357.

Chahal, P.P.K., Singh, I. and Chahal, V.P.S. 1983. Interaction between different population levels of Meloidogyne incognita and Rhizobium on green gram. Journal of Research Punjab Agricultural University, 20: 399-402.

F.A.O. 2014. FAO Statistical Yearbook 2014. Europe and Central Asia Food and Agriculture, Budapest, Hungary.

Gaur, H.S., Singh, R.V., Kumar, S., Kumar, V. and Singh, J.V. 2001. Search for nematode resistance in crops. AICRP on nematodes, Division of Nematology, IARI, New Delhi Publication, p. 84.

Hayat, A. 2011. Screening of potato cultivars against root knot nematode (Meloidogyne incognita) and its management through organic amendments. M.Sc. Thesis. Department of Plant Pathology University of Agriculture, Faisalabad, Pakistan.

Hussain, M.A., Mukhtar, T. and Kayani, M.Z. 2011. Efficacy evaluation of Azadirachta indica, Calotropis procera, Datura stramonium and Tagetes erecta against root-knot nematodes Meloidogyne incognita. Pakistan Journal of Botany (Special Issue), 43: 197-204.

Irshad, U., Mukhtar, T., Ashfaq, M., Kayani, M.Z., Kayani, S.B., Hanif, M. and Aslam, S. 2012. Pathogenicity of citrus nematode (Tylenchulus semipenetrans) on Citrus jambhiri. Journal of Animal and Plant Sciences, 22: 1014-1018.

Lu, P., Davis, R.F., Kemerait, R.C., lersel, M.W. and Scherm, H. 2014. Physiological Effects of Meloidogyne incognita Infection on Cotton Genotypes with Differing Levels of Resistance in the Greenhouse. Journal of Nematology, 46(4): 352-359.

MacKinney, G. 1941. Absorption of light by chlorophyll solutions. Journal of Biological Chemistry, 140: 315-322.

Melakeberhan, H., Webster, J.M. and Brooke, R.C. 1987. Relationship between physiological response and yield loss of different age French bean to Meloidogyne incognita. Plant Pathology, 35: 203-213.

Melakeberhan, H., Webster, J.M., Brooke, R.C., D'Auria, M. and Cackette, M. 1986. Effect of Meloidogyne incognita on plant nutrient concentration and its influence on physiology of beans. Journal of Nematology, 19: 324-330.

Montasser, S.A., Mahmoud, N.A., El-Mesalamy, A.F. and Abdel-Mageed, M.A.A. 2017. Evaluation of six leguminous crops against the root-knot nematode, Meloidogyne javanica infection. Pakistan Journal of Nematology, 35(1): 79-84.

Mukhtar, T., Hussain, M.A., Kayani, M.Z. and Aslam, M.N. 2014. Evaluation of resistance to root-knot nematode (Meloidogyne incognita) in okra cultivars. Crop Protection, 56: 25-30.

Oostenbrink, M. 1966. Major characteristics of the relationships between nematodes and plants. 
Meded. Land. gesch. Wageningen, 66: 1-46.

Pandey, R.K., Nayak, D.K. and Kar, R. 2016. Effects of chlorophyll contents of green gram varieties/ lines as influenced by root-knot nematode $\mathrm{Mel}$ oidogyne incognita. International Journal of Current Research in Biosciences Plant Biology, 3(11): 17-22.

Sasser, J.N. 1954. Identification and host-parasite relationships of certain root-knot nematodes (Meloidogyne spp.). Bulletin of the Maryland Agricutural Experiment Station A-77 (Tech.), p. 31.

Sasser, J.N. and Taylor, A.L. 1978. Biology, identification and control of root-knot nematodes (Meloidogyne spp.). Raleigh, NC: North Carolina State University Graphics, p. 111.

Sikora, R.A. and Fernandez, E. 2005. Nematode parasites of vegetables. In:"Plant parasitic nematodes in subtropical and tropical agriculture" (Eds.- Luc, M., Sikora, R.A. and Bridge, J.), 2nd edition, CABI publishing, 319-392.
Swain, B. and Prasad, J.S. 1988. Chlorophyll content in rice as influenced by the root-knot nematode, Meloidogyne graminicola infection. Current Science, 57: 895-896.

Tariq, M., Khan, T.A., Akhtar, G. and Khan, N. 2016. Screening of Fenugreek (Trigonella foenumGraecum) Varieties against Root-knot Nematode (Meloidogyne incognita). Journal of Plant Pathology and Microbiology, 7: 1-4.

Vagelas, I. and Gowen, S.R. 2012. Control of Fusarium oxysporum and root-knot nematodes (Meloidogyne spp.) with Pseudomonas oryzihabitans. Pakistan Journal of Phytopathology, 24: 32-38.

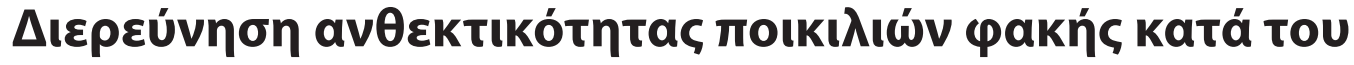

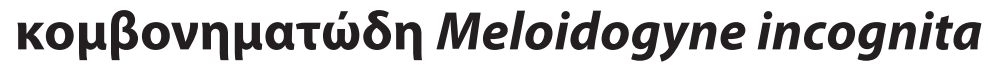

\author{
T. Ansari, M. Asif kaı M.A. Siddiqui
}

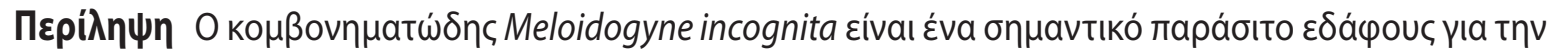

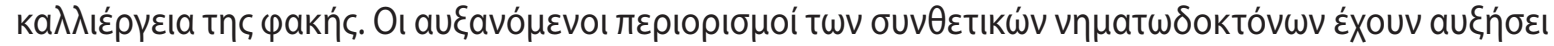

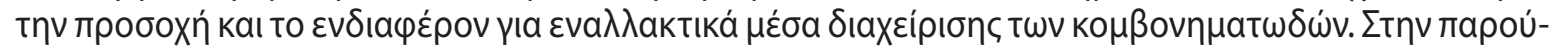

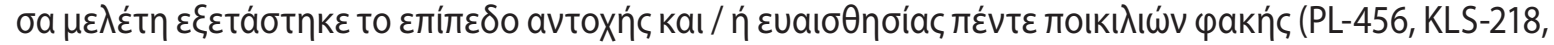

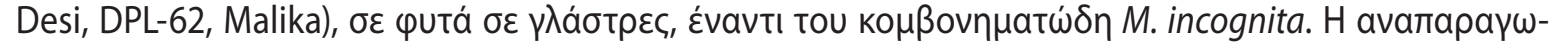

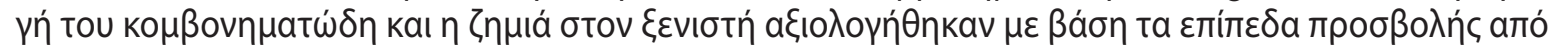

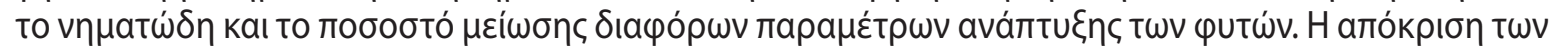

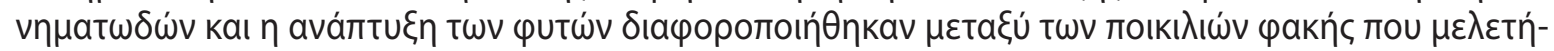

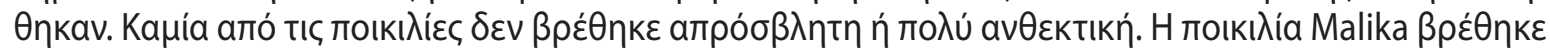

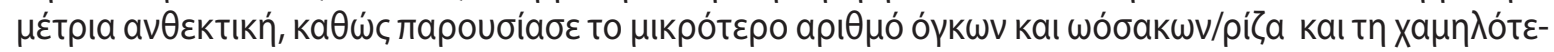

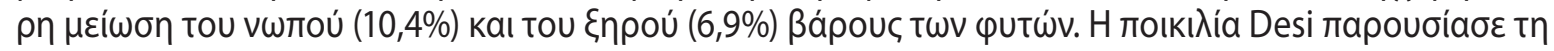

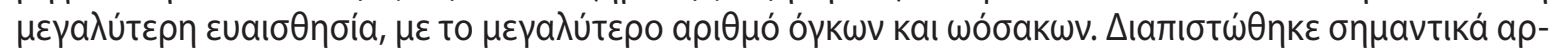

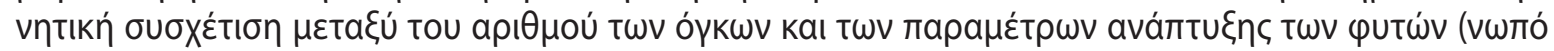

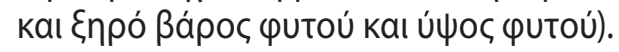

